\title{
ROOT ANATOMY OF GALEANDRA LEPTOCERAS (ORCHIDACEAE)
}

\author{
Leila E. Barretta-dos-Santos ${ }^{1}$, Jéssica Sant'Ana ${ }^{1}$, Adarilda Petini-Benelli² \& \\ Cristiano Pedroso-De-Moraes ${ }^{1,3}$ \\ ${ }^{1}$ Biological Science Department of Hermínio Ometto University Center - UNIARARAS. Rua \\ Maximiliano Baruto, 500, Jd. Universitário. CEP: 13.607-339. Araras/SP. Brasil \\ ${ }^{2}$ Federal University of Mato Grosso, Herbarium-Botany Department, P.O. Box 198, Centro, \\ CEP: 78005-970. Cuiabá/MT. Brasil \\ ${ }^{3}$ cpmoraes@gmail.com
}

\begin{abstract}
Due to the scarce information about the root organization of Galeandra genus representatives, this study aimed to describe the root anatomy of Galeandra leptoceras, describing adaptations related to hydric relations and characters of taxonomic interest. Five roots of three plants were fixed and preserved in $50 \%$ alcohol. These ones were cut in midline with the use of razors. The sections were stained with $0.05 \%$ Safrablau and mounted in glycerin. It was observed that the roots of species are structurally adapted to epiphytism; however, some anatomical features show that this species requires more frequent watering or environments with constant humidity. The anatomical characteristics described for roots support results reported by authors that include the genus in subtribe Catasetinae, Cymbidieae tribe. The anatomical characters have generic uniformity, serving as a tool for the genus's systematic.
\end{abstract}

KEY WORDS: Roots, orchid, morphoanatomy, adaptation

Introduction. Orchidaceae is one of the largest families of monocots and includes about 850 genera and 25,000 species (Atwood 1986) prevalent in the tropics (Pabst \& Dungs 1975, 1977).

The cultivation of orchid species is considered very important commercially. This is valid for Brazilian floriculture agribusiness, mainly due to the large capacity for genetic recombination, beauty, shape, size and the durability of the flowers which are presented in several species (Zanenga-Godoy \& Costa 2003).

The Neotropical genus Galeandra Lindl. includes about 18 species distributed from southern Florida to northwest Argentina (Monteiro et al. 2010). The majority of species are found in Brazil, which is why the country is considered a diversity center, owning 16 valid taxa and two national endemic species (Barros et al. 2014). All representatives of genus are herbaceous with cylindrical-fusiform or ovoid, short and thickened pseudobulbs, according to the habit which can be epiphytic or terrestrial. The most striking features to distinguish between species are the presence or absence of trichomes on the surface of the lip and column, the number of keels and the shape of the lip when spread (Monteiro et al. 2009).

Galeandra was included in subtribe Cyrtopodiinae by Dressler, however, this classification was based solely on morphological characters, especially: presenting pseudobulbs with several internodes, distichous leaves, resupinate flowers and complete pollinarium (Dressler 1993). On the other hand, several recent phylogenetic analyzes of the Catasetinae subtribe based on nuclear DNA sequences (ITS) and plastid (rps4) involving some species of Galeandra resulted in their inclusion in Catasetinae (Pridgeon \& Chase 1998). Pridgeon et al. (2009) considering that there is not a single character that can connect Galeandra to Catasetinae subtribe other than homoblastics pseudobulbs. However, Freudenstein et al. (2004) obtained a very significant result in their studies. Using a combination of $r b c L$ and $m a t K$, the relationship was evident, standing Galeandra as a brother clade supported on jackknife for $100 \%$. Besides those already mentioned, other studies involving molecular analyzes, highlight the possible positioning of Galeandra in Catasetinae subtribe (Chase 2003, Pridgeon et al. 2009). Demonstrably it is a monophyletic group (Monteiro et al. 2010).

Among the species that comprise the genus, Galeandra leptoceras Schltr. is one of the most known. Originated in Colombia, it lives in tropical areas, 
showing epiphytic habit, small size, and carrying up to five cylindrical pseudobulbs with lanceolate, acuminate, plicate and glabrous leaves possessing three to five ribs. The racemes type inflorescence is terminal, with approximately $5 \mathrm{~cm}$ in length and number of flowers ranging from five to seven. The flexuous, thin and upright inflorescence, presents elliptic-lanceolate floral bracts and acuminate format (Schlechter 1920).

Vegetatively, the roots of orchids in general spread over the surface of its phorophytes to absorb available nutrients. These are often present themselves infected with mycorrhizal fungi, which are responsible for facilitating the absorption of minerals by plants in a mutualistic and harmonious relationship. Such organs are anatomically defined by multistratified epidermis called velamen (Pridgeon 1987, Porembski \& Barthlott 1988), which has the function to absorb and deliver water from the vicinity of the rhizosphere ceding it to other tissues during drought periods (Pridgeon 1987, Pedroso-de-Moraes 2000, Moraes \& Almeida 2004).

Anatomical descriptions of roots are used as tool for taxonomic identifications (Porembski \& Barthlott 1988 ) in correlation with molecular data (Pedrosode-Moraes et al. 2012, 2013) and allow to find if in high humidity environments, constant irrigation can be dispensed so that the excess of water does not generate the decay of these organs (Pedroso-de-Moraes 2000).

Thus, besides the enrichment of systematic and anatomical knowledge, the description of the radicular anatomy characters in orchid species can be assisted in the development of efficient management techniques, aiming to improve phytotechnical aspects of plants for sale at the same time reducing production costs related to water use (Pedroso-de-Moraes et al. 2013).

This study aimed to describe the anatomical radicular organization in Galeandra leptoceras indicating hydric adaptations for epiphytism, which can be used in cultivation, and anatomical characters of taxonomic interest.

\section{Materials and Methods}

Botanical material -. The material comes from the Live Collection of Uniararas (greenhouse with 70\% shading, subjected to daily irrigation) of Centro Universitário Hermínio Ometto - Uniararas, Araras (SP) (VHO) and corresponds to the following specifications: Galeandra leptoceras Schltr. (VHO: 63, 68, 72).
Anatomical evaluations - . To evaluate the root anatomy, five organs with an average length of $7 \pm 1,5$ $\mathrm{cm}$ of three adult plants (six years in culture) were fixed in FAA 50\% and preserved in 50\% alcohol (Johansen 1940). Each one was sectioned in the midline, with the aid of razors. Transverse sections were subjected to double staining with $0.05 \%$ Safrablau (Bukatsh 1972) and mounted in glycerin. For starch identification Lugol solution was used (Bücherl 1962); for lignin staining with hydrochloric phloroglucin (Jansen 1962); for lipids with Sudan III (Johansen 1940); and flavonoids with potassium hydroxide (Costa 1982). The most important aspects were recorded with a digital camera attached to a Olympus microscope (Model BX51).

Results. The cross section in roots of Galeandra leptoceras Schltr. f. \& Warm, showed three distinct regions: velamen, parenchymatous cortex and vascular cylinder (Fig. 1A-C).

In cross section the velamen shows polygonal and elliptical cells and consists of 4-5 layers (Fig. 1AB). The more external layer in velamen, referred as epivelamen, is formed by flat periclinally cells and the underlying layers are composed of larger and radially elongated cells.

The epivelamen features smaller cells than the inner layers. The endovelamen is formed by isodiametric cells possessing narrow and spiral thickenings (Fig. 1B).

The cortex has three distinct regions: exodermis, the layer below velamen, cortex and endodermis (Fig. 1A-B). The exodermic cells are isodiametric and bigger in relation to the other cortical layers. These present walls with little thickness except for the periclinal external wall, in which, histochemical tests with hydrochloric acid plus phloroglucin and Sudan III revealed the presence of lignin and suberin (Fig. 1B). Internally the exodermis, the cortical parenchyma, relatively developed, consists of 11-12 layers of parenchyma cells. These layers are generally formed by isodiametric, rounded and cells of different sizes, defining small triangular intercellular spaces (Fig. 1A-B). Common observations are mycorrhizal arbuscules near the exodermis (Fig. 1D) and crystals of calcium oxalate raphides type in idioblasts distributed throughout the cortex (Fig. 1F). Unistratified endodermis presents isodiametric cells with thickening 

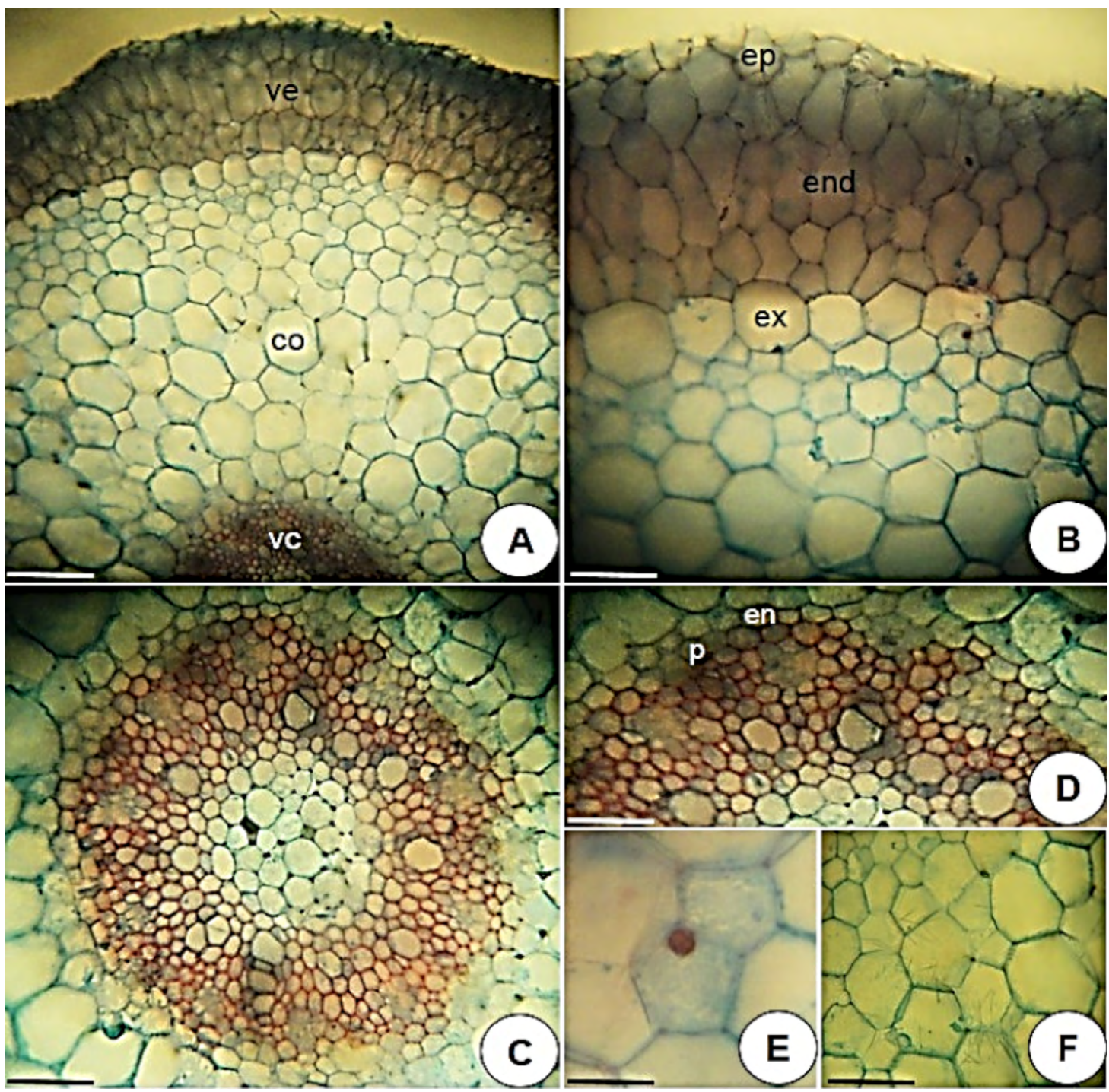

Figure 1 - Cross sections in roots of GaleandraleptocerasSchltr.f. A) general appearance of the epidermis and cortex; B) exoderm detail; C) vascular cylinder; D) endodermis and pericycle; E) fungal arbuscule; F) calcium oxalate raphids. co $=$ cortex $; \mathrm{n}=$ endoderm; end = endovelamen; $\mathrm{p}=$ epivelamen; $\mathrm{ex}=$ exoderm; $\mathrm{p}=$ pericycle; $\mathrm{ve}=$ velamen; $\mathrm{vc}=\mathrm{vascular}$ cylinder. Bars $=\mathrm{A}$ and $\mathrm{D}=100 \mu \mathrm{m} ; \mathrm{E}$ and $\mathrm{F}=50 \mu \mathrm{m}$.

in the internal periclinal and anticlinal walls, except for the passage cells, which have thin walls (Fig. 1C$\mathrm{D})$. The root of $G$. leptoceras is poliarc and shows ten protoxylem poles. The medulla is formed by nonlignified parenchyma cells possessing thin walls and the presence of triangular cell spaces (Fig. 1C).

Discussion. The velamen is comprised by a specialized epidermis that consists of multiple layers of cells with thin walls, being bounded internally by the cortex. Ontogenetic studies in roots of orchids proved the origin of such tissue from periclinal divisions of protodermic cells and defined it as originating from dead cells, bearing secondarily thickened walls and filled with air when not hydrated (Pridgeon 1987).

The velamen, besides described for Orchidaceae, is also recognized in other plant families, such as: Araceae, Liliaceae, Dioscoreaceae, Taccaceae, Ama- 
ryllidaceae and Commelinaceae (Dahlgren et al. 1985). This tissue protects the interior of the root avoiding heating and consequent water loss; and also preventing the excessive accumulation of this element (Pridgeon 1987, Gonzaga \& Gonzaga 1996). The existence of the canopy is related to epiphytism (Engard 1944, Dycus \& Knudson1957), however, this tissue may also occur less frequently in terrestrial orchids (Porembski \& Barthlott 1988, Stern et al. 1993a, 1993b, Kurzweil et al. 1995).

In some Catasetinae, the tissue presents itself welldeveloped, for example, in Mormodes tapoayensis F.E.L. Miranda \& K.G. Lacerda, where the velamen is constituted by eight layers (Stern \& Judd 2001). However, for many species of Catasetum L. C. Rich. and Cycnoches Lindl. genera, an average number of layers between 4-6 is reported (Stern \& Judd 2001; Pedroso-de-Moraes et al. 2012).

The velamen is usually divided into two parts: the epivelamen and endovelamen. The epivelamen arises from deeper tissue layers and its cells do not present protoplasts in maturity (Shushan 1959, Sanford \& Andalawo 1973, Noel 1974). As in other Catasetinae, particularly for most species of Mormodes Lindl. genus, epivelamen cells are smaller than the endovelamen ones (Stern \& Judd 2001), having this character been clearly demonstrated for the species Mormodes sinuate Rchb.f. \& Warm. (Pedroso-deMoraes et al. 2013).

It was found in the examined roots that the composition of the cell walls in velamen is of cellulose with different degrees of impregnation for lignin and suberin, with a degree of lignification and suberization that can vary widely between species of orchids (Noel 1974, Benzing et al. 1983). Furthermore, one of the possible functions of the wall thickening in velamen is to provide support and prevent cell collapse during drying (Noel 1974).

It is common in the inner layer of velamen of the roots of orchids, the presence of specialized cells called tilossomes, which assist in condensation of water vapor and other gases (Pridgeon 1987). However, these cells are absent in Catasetinae, therefore they do not appear in Galeandra leptoceras nor in Catasetum barbatum (Lindl.) Lindl., Catasetum fimbriatum (C. Morren.) Lindl.,
Catasetum gnomus Linden \& Rchb. f., Catasetum viridiflavum Hook., Clowesia amazonica K. G. Lacerda \& V. P. Castro and M. sinuata (Stern \&Judd 2001, Pedroso-de-Moraes et al. 2012; 2013).

In the analyzed root, the cortical region showed a unistratified exodermis and the existence of thickening in the outer tangential wall, which was also observed for C. fimbriatum (Oliveira \& Sajo 1999), to M. sinuata (Pedroso-de-Moraes et al. 2013) and several representatives of the genus Mormodes (Stern \& Judd 2001). The set exoderm-velamen functions as a system in which long suberized and lignified exodermic cells protect cortical parenchyma against desiccation (Haberlandt 1914).

The number of layers in velamen, in cortex and the poles of protoxylem are anatomical characteristics that may influence the radicular diameter (Moreira \& Isaias 2008, Pedroso-de-Moraes et al. 2012). However, each one shall exercise in greater or lesser extent the overall diameter, the environment, in turn, influence the development of these tissues and radicular structures and hence in diameter (Pedrosode-Moraes et al. 2013).

This relationship was confirmed in studies with different plants, in which it was found that in environments characterized by water scarcity, a reduced number of cortical layers are found in plant species, suggesting that the shortest distance between the substrate and the stele facilitate the absorption of water under these circumstances (Fahn 1982). Still, radicular anatomic differences were found in roots of cultivars of sugar cane developed in different soil conditions: dry, wet and irrigated. The relationship between the measurements of the thickness of the cortex and vascular cylinder were higher in irrigated or waterlogged soils than in dry. Also, the thickening in cell walls of parenchyma occurring between the poles of xylem and phloem throughout development, were higher for roots in the cultivar developed under dry conditions (Venkatraman \& Thomas 1922).

There is a relationship between the root diameter and the number of poles of protoxylem (Rütter \& Stern 1992) in which roots of larger diameter, usually present more poles (Rosso 1966). However, this number varies in genus, according to different roots of the same species and the same root in different 
height levels (Rütter \& Stern 1992).

Mycorrhizal fungi are always present in habitats of orchids because they are essential for germination, development and distribution of such plants (Piccoli et al. 2014). Thus, larger populations of fungi are found near mature orchids (Perkins \& McGee 1995, Batty et al. 2001, Otero et al. 2004, Diez 2007), which directly leads to the observation of mycorrhizal arbuscules often present in the radicular cortices of orchids as Catasetinae. The presence of raphides in different plant organs is common in Orchidaceae (Metcalfe 1963). Idioblasts with raphides are formed by cells produced by unequal divisions in the meristem (Shushan 1959, Chiang 1970).

The endodermis is unistratified and their isodiametric cells present thickening in $\mathrm{O}$, such as M. sinuata (Pedroso-de-Moraes et al. 2013) and most Catasetinae (Stern \& Judd 2001, Pedroso-de-Moraes et al.2012).

The roots of orchids can be classified into 12 types according to the occurrence and combination of the following characters: epivelamen, number of layers of velamen, type of wall thickening in velamen and exodermis cells and number of cell layers in the cortex (Porembski \& Barthlott, 1988). The root of the studied species matches the type Cymbidium by owning epivelamen, exodermis with external tangential thickening and over eight cortical cell layers. This uniformity among the roots corroborates the results of Chase et al. (2003), which recognize a single monophyletic tribe - Cymbidieae formed by Maxillareae, Cymbidiinae, Eulophiinae, Bromheadiinae and Catasetinae. Still, the anatomical features found in the roots of Galeandra lepdoceras corroborate and support the anatomical findings by Stern and Judd (2001) and highlighted by Pridgeon et al. (2009). Furthermore, the observed characters have found certain uniformity with Catasetinae species, which can serve as a tool for the subtribe systematic.

Conclusion. The roots of the studied species presents structural characters that represent adaptation to epiphytic habit, moreover, the presence of 4-5 layers in velamen and 11-12 layers in cortex, shows that such plants require more frequent watering or environment with constant humidity, as found in their natural habitat.

\section{LiteRATURE CITED}

Atwood, J. T. (1986). The size of Orchidaceae and the systematic distribution of epiphytic orchids. Selbyana, 9, 171-186.

Barros, F de., Vinhos, F., Rodrigues, V. T., Barberena, F. F. V. A., Fraga, C. N., Pessoa, E. M., Forster, W., Menini Neto, L., Furtado, S. G., Nardy, C., Azevedo, C. O., Guimarães, L. R. S. (2014). Orchidaceae in Lista de Espécies da Flora do Brasil. Jardim Botânico do Rio de Janeiro. Available in: $<$ http://reflora.jbrj.gov.br/jabot/floradobrasil/FB11597>.

Batty, A. L., Dixon, K. W., Brundrett, M. \& Sivasithamparam, K. (2001). Constraints to symbiotic germination of terrestrial orchid seed in a Mediterranean bushland. New Phytologist ,152, 511-520.

Benzing, D. H., Friedman, W. E., Peterson, G. \& Renfrow, A. (1983). Shootlessness, velamentous roots, and the pre-eminence of Orchidaceae in the epiphytic biotope. American Journal of Botany, 70, 121-133.

Bücherl, W. (1962). Técnica microscópica. São Paulo: Polígono.

Bukatsh, F. (1972). Benerkemgem zeir doppelfarbeing astrablau-safranina. Microkosmos, 61, 255-256.

Chase, M. W., Cameron, K. M., Barrett, R. L. \& Freudestein, J. V. (2003). DNA data and Orchidaceae systematics: a new phylogenic classification. In: K. W. Dixon, S. P. Kell, R. L. Barrett \& P. J. Cribb (Eds.), Orchid conservation (pp.69-89). Sabah: Natural History Publications.

Chiang, S. H. T. (1970). Development of the root of Dendrobium kwashotense Hay. with special reference to the celular structure of its exodermis and velamen. Taiwania, 15, 1-16.

Costa, A. F. (1982). Farmacognosia. Lisboa: Fundação Calouste Gulbenkian.

Dahlgren, R. M. T., Clifford, H. T. \& Yeo, P. F. (1985). The families of the Monocotyledons: structure, evolution and taxonomy. Berlin: Springer-Verlag.

Diez, J. M. (2007). Hierarchical patterns of symbiotic orchid germination linked to adult proximity and environmental gradients. Journal of Ecology, 95, 159-170.

Dressler, L. R. (1993). Phylogeny and classification on the orchid family. Portland: Dioscorides Press.

Dycus, A. M. \& Knudson, L. (1957). The role of the velamen of the aerial roots of orchids. Botanical Gazette, 119, 78-87.

Engard, C. J. (1944). Morphological identity of the velamen and exodermis in orchid. Botanical Gazette, 105, 457-462.

Fahn, A. (1982). Plant anatomy. Oxford: Pergamon Press.

Foldats, E. (1970). Orchidaceae. In: T. Lesser. Flora de Venezuela (pp. 498-514). Venezuela: Instituto Botánico.

Freudenstein, J. van den Berg, C., Goldman, D. H., Kores, P. J., Molvray, M. \& Chase, M. W. (2004). An expanded plastid DNA phylogeny of Orchidaceae and analysis of 
jackknife branch support strategy. American Journal of Botany, 91, 149-57.

Gonzaga, M. E. B. \& Gonzaga, A. L. A. (1996). Estrutura das orquídeas. Boletim Catarinense de Orquídeas $e$ Bromélias, 4, 2-3.

Haberlandt, G. F. J. (1914). Physiological plant anatomy. London: Macmillan Co.

Jansen, W. A. (1962). Botanical histochemistry. San Francisco: H.H. Freeman and Co.

Johansen, D. A. (1940). Plant microtechnique. New York: Mc Graw Hill.

Kurzweil, H., Linder, H. P., Stern, W. L. \& Pridgeon, A. M. (1995). Comparative vegetative anatomy and classification of Diseae (Orchidaceae). Botanical Journal of the Linnean Society, 117, 171-220.

Metcalfe, C. R. (1963). Comparative anatomy as a modern Botanical discipline. In: R. D. Preston (Ed.), Advances in botanical research, VI (pp. 101-147). New York: Academic Press.

Monteiro, S. H. N., Fernandes da Silva, M. F. \& de Souza Secco, R. (2009). O gênero Galeandra (Orchidaceae) na Amazônia Brasileira. Revista Acta Amazônica, 39, 21-34.

Monteiro, S. H. N., Selbach-Schnadelbach, A., de Oliveira, R. P. \& van den Berg, C. (2010). Molecular phylogenetics of Galeandra (Orchidaceae: Catasetinae) based on plastid and nuclear DNA sequences. Systematic Botany, 35, 476-486.

Moraes, C. P. \& de Almeida, M. (2004). Influência climática sobre a plasticidade fenotípica floral de Catasetum fimbriatum Lindley. Ciência e Agrotecnologia, 28, 942-948.

Moreira, A. S. F. P. \& Isaias, R. M. S. (2008). Comparative anatomy of the absorption roots of terrestrial and epiphytic orchids. Brazilian Archives of Biology and Technology, 51, 83-93.

Noel, A. R. A. (1974). Aspects of cell wall structure and development of the velamen in Ansellia gigantea Reichb. f. Annals of Botany, 38, 495-504.

Otero, J. T., Ackerman, J. D. \& Bayman, P. (2004). Differences in mycorrhizal preferences between two tropical orchids. Molecular Ecology, 13, 2393-2404.

Pabst, G. F. J. \& Dungs, F. (1975). Orchidaceae Brasilienses, v. 1. Hildesheim: Kurt Schmersow.

Pabst, G. F. J. \& Dungs, F. (1977). Orchidaceae Brasilienses, v. 2. Hildesheim: Kurt Schmersow.

Pedroso-de-Moraes, C. (2000). Cultivo de orquídeas. Araras: Biblioteca Duse Rüegger Ometto.

Pedroso-de-Moraes, C., Rodrigues de Moura, E. R., Cerri e Silva, M. \& Abdalla, M. A. (2007). As orquídeas e o mercado. Boletim da Coordenadoria das Associações Orquidófilas do Brasil (CAOB), 66, 36-42.

Pedroso-de-Moraes, C. \& Almeida, M. (2005). Estudo morfoanatômico do ginostêmio de Catasetum fimbriatum Lindley. Orquidário, 19, 84-90.
Pedroso-de-Moraes, C., Brescansin, R. L., Merenciano, F. C., Paraluppi, A. L. \& de Souza-Leal, T. (2013). Anatomia radicial de Mormodes sinuata Rchb. f. \& Warm. (Catasetinae, Cymbidieae: Orchidaceae). RAMA: Revista em Agronegócios e Meio Ambiente, 6, 311-323.

Pedroso-de-Moraes, C., de Souza-Leal, T., Brescansin, R. L., Pettini-Benelli, A. \& Sajo, M. (2012). Radicular anatomy of twelve representatives of the Catasetinae subtribe (Orchidaceae: Cymbidieae). Anais da Academia Brasileira de Ciências, 84, 455-467.

Perkins, A. J. \& McGee, P. A. (1995). Distribution of the orchid mycorrhizal fungus Rhizoctonia solani, in relation to its host Pterostylis acuminata. Australian Journal of Botany, 43, 565-575.

Piccoli, M. C. A., de Souza-Leal, T. \& Pedroso-de-Moraes, C. (2014). Distribuição espacial de Sacoila lanceolata (Aubl.) Garay (Orchidaceae) em fragmento mesófilo de Pirassununga, São Paulo, Brasil. Nucleus, 11, 115-130.

Porembski, S. \& Barthlott, W. (1988). Velamen radicul micromorphology and classification of Orchidaceae. Nordic Journal of Botany, 8, 117-137.

Pridgeon, A. M. (1987). The velamen and exodermis of orchid roots. In: J. Arditti. Orchid biology: reviews and perspectives (pp. 30-56). Ithaca: Cornell University Press.

Pridgeon, A. M. \& Chase, M. W. (1998). Phylogenetic of subtribe Catasetinae (Orchidaceae) from nuclear and chloroplast DNA sequences. In: C. E. B. Pereira. Proceedings of the $15^{\text {th }}$ World Orchid Conference, Rio de Janeiro 1996 (pp. 275-281). France: Naturalia Publications. Pridgeon, A. M., Cribb, P., Chase, M. W. \& Rasmussen, F. N. (2009). Genera Orchidacearum, vol. 5: Epidendroideae (part two). Oxford: Oxford University Press.

Rosso, S. W. (1966). The vegetative anatomy of the Cypripedioideae (Orchidaceae). Journal of the Linnean Society (Botany), 59, 309-341.

Rütter, B. E. \& Stern, W. L. (1992). An assessment of quantitative features of velamen stratification and protoxylem strands in roots of Orchidaceae. Lindleyana, 9, 219- 225.

Sanford, W. W. \& Adanlawo, I. (1973). Velamen and exodermis characters of West African epiphytic orchids in relation to taxonomic grouping and habitat tolerance. Botanical Journal of the Linnean Society, 66, 307-321.

Schlechter, R. (1920). Orchidaceae novae etcriticae. Repertorium Specierum Novarum Regni Vegetabilis,16, 437-450.

Shushan, S. (1959). Developmental anatomy of orchid Cattleya $\times$ Trimos. In: C. L. Withner. The orchid: scientific studies (pp.45-72). New York: Wiley.

Stern, W. L. \& Judd, W. S. (2001). Comparative anatomy and systematics of Catasetinae (Orchidaceae). Botanical Journal of the Linnean Society, 136, 153-178.

Stern, W. L., Morris, M. W., Judd, W. S., Pridgeon, A. M. \& Dressler, R. L. (1993a). Comparative vegetative anatomy 
and systematics of Spiranthoideae (Orchidaceae). root systems: studies in development and anatomy. Botanical Journal of the Linnean Society, 113, 162-197. Agricultural Journal of India, 17, 381-388.

Stern, W. L., Ceadle, V. I. \& Torsch, J. (1993b). Apostasiads, systematic anatomy, and the origins of Orchidaceae. Botanical Journal of the Linnean Society, 111, 411-455.

Venkatraman, T. S. \& R. Thomas. (1922). Sugarcane Zanenga-Godoy, R. \& Costa, C. G. (2003). Anatomia foliar de quatro espécies do gênero Cattleya Lindl. (Orchidaceae) do Planalto Central Brasileiro. Acta Botanica Brasilica, 17, 101-118. 